Paediatrica Indonesiana 16 : 299 - 304. Sept. - Oct. 1976.

From the Department of Child Health, Dr. Kariadi Hospital/Medical School, University of Diponegoro, Semarang

\title{
Adoption at Dr. Kariadi Hospital Semarang
}

by

SOETADJI N., MOELJONO S. TRASTOTENOJO, R. HARIJONO, SOERARJO DARSONO, SITI ALFINAH, and DJOKO WASIODO

\section{Abstract}

Procedures and other arrangements concerning adoption at Dr. Kariadi Hospital, Senarang, is discussed in this paper. From 1969 to the first three months of 1974, 41 children with ages ranging between 5 days and 3 years old have been adopted. A visit to 18 of them showed that their health condition was satisfactory; a psychological evaluation also indicated that no mental retardation was observed, excepting that their I.Q. level was difficult to determine. Five children received official approval from the court, one from the notary and the others from the local District Head (Lurah/Canat).

Received 14th. Dec. 1974. 


\section{Introduction}

In the efforts to raise the children welfare, both physically and mentally, provision of food, clothing, housing, education, love, etc. are essential. Government and private institutions have created places for recreation, consulting bureaux, work camps, youth camps, care institutions, and others.

Care Institutions here comprise Home Care, Foster Care, and Adoption. In the Home Care, homeless children who have problems in their physical and mental development, but lacking parental love and affection, are aided. Many of the Home Cares in Indonesia have long been established. Foster Cares are only a recent development. There have been about 139 families in Central Java who have taken care of 172 children; they are in Pemalang, Purwokerto, and Blora. Unlike in the Home Care, children in the Foster Care are accepted as part of the whole family, but with an exception that their rights are limited only to receiving education and keeping the housework of the family. Adoption, though local by tradition, has rooted long in Indonesia.

\section{The adoption}

The hospital has approached the problems of unwanted children with great responsibility. They were formerly put in the Home Care, but now they are sent to the Social Pediatrics, a new institution which has been chosen to take care of unwanted children since 1969. Adoption requirements and its arrangements: As guardian of unwanted children, the hos- pital is concerned with both the children's needs and their parents' rights. Any parent who wish to adopt a child from the hospital have to fulfil the following requirements -

I. Application letter: the application form must be completed and submitted to the Director of Dr. Kariadi Hospital Semarang. The items in the form include full name of applicant, address, employment, reasons, etc.; the form is to be endorsed by the local District Head (Lu$\mathrm{rah} /$ Camat).

II. Health Certificate accompanied by a chest X-ray is to be obtained from a doctor.

III. Approval from the local court: one year at the latest after the family have adopted the child, they should have received an official approval concerning their adoption from the local court. Before it is made official, the child is still in the status of being entrusted to the family.

\section{The adopted children}

Only children who are not wanted by their parents may be adopted. In general, they are abandoned because of several reasons :

- unwanted birth of baby

- death of mother while delivering the baby

- socio-economic burden not permitting to take care of many children

- leaving the baby without notice from their parents to the hospital.

These children may be adopted when their parents have submitted a letter of transfer to the hospital, endorsed by the local District Head (Lurah/Camat). When no letter of transfer is available, and the time to discharge the baby has come and 3 month thereafter the baby is still not taken home, the hospital is then charged with the responsibility of taking care the baby.

TABLE 1: The age of the adopted children

\begin{tabular}{|c|c|c|c|c|c|c|c|c|c|c|c|c|c|c|}
\hline & \multicolumn{13}{|c|}{ A g e (months) } & \multirow{2}{*}{ Total } \\
\hline & 1 & 2 & 3 & 4 & 5 & 6 & 7 & 8 & 9 & 10 & 11 & 12 & 36 & \\
\hline 1969 & 1 & 1 & - & 3 & 2 & 2 & - & - & 1 & - & - & 1 & - & 1.1 \\
\hline 1970 & 1 & - & - & 1 & - & 1 & 3 & - & - & - & 1 & - & - & 7 \\
\hline 1971 & - & - & 1 & 2 & 2 & 1 & 1 & 2 & 1 & - & - & - & - & 10 \\
\hline 1972 & - & - & - & 1 & 1 & - & 1 & - & - & - & - & - & - & 4 \\
\hline 1973 & - & - & 3 & 2 & 2 & 1 & - & - & - & - & - & - & 一 & 8 \\
\hline 1974 & - & - & - & - & - & - & - & - & 一 & - & - & - & - & 1 \\
\hline '69-'74 & 2 & 1 & 4 & 9 & 7 & 5 & 5 & 2 & 2 & 1 & 1 & 1 & 1 & 41 \\
\hline
\end{tabular}

\section{The foster parents}

Any interested person is welcome to adopt a child from Dr. Kariadi Hospital. He should submit the application letter to the Director of the Hospital who will decide whether his application is granted or not. Forty-one children have already been adopted. Their foster parents came from Semarang (25), Central Jawa (13 outside Semarang), Jakarta (2), and Kalimantan (1). Their social standings varied from farmers, merchants, drivers, private and government employees, to military personnels. None of them had
Since 1969 up to the first three months of 1974 there have been 41 children adopted, varying in ages between 5 days to 3 years old. All of them were in good health, but not all problems concerning hereditary problems could be reported. We admit that it was difficult to obtain information from their parents. 
not only to complete the form, but are to be visited also by social workers as well. This visit is to ensure direct and reliable. informations about their interest in adopting children. We consider this visit essential so as to ascertain their' sincerity morally, spiritually, and finan-

cially. The information obtained is then reported to the Department of Social $\mathrm{Pe}$ diatrics to get some evaluation. Then the final decision to grant the application rests upon the Director of Dr. Kariadi Hospital, Semarang.

TABLE 2: Classification of foster parents

\begin{tabular}{|c|c|c|c|c|c|}
\hline \multirow{2}{*}{ Social classes } & \multicolumn{4}{|c|}{ A rea of origin } & \multirow{2}{*}{ Total } \\
\hline & Semarang & Central Java & Jakarta & Kalimantan & \\
\hline Military pers. & 1 & - & 2 & - & 3 \\
\hline Govt. employees & 9 & 一 & - & - & 9 \\
\hline Priv. employees & 3 & 3 & - & - & 6 \\
\hline Farmers & - & 8 & - & - & 8 \\
\hline Merchants & 6 & 1 & - & 1 & 8 \\
\hline Drivers & 2 & 1 & $一$ & - & 3 \\
\hline Miscellaneous & 4 & - & - & - & 4 \\
\hline$T \circ t a 1$ & 25 & 13 & 2 & 1 & 41 \\
\hline
\end{tabular}

Most parents who submitted their application letters had no children themselves. One of them had adopted a gir who was at that time 14 years old; another couple had already 5 children. They have now grown up into mature children. A visit have been made to 18 foster parents; a couple were happy enough that the wife became pregnant soon after the coming of their adopted child. A baby girl was born to this family and lived happily since then.

The status of the child in the family As conditioned in the letter of agreement between the Director and the foster parents, the latter should seek legal ap- by foster parents who are Government's employees. In short, 5 out of 18 children have been legally approved as adopted children by the court. We consider that the other 13 children are entrusted to the applicants.

\section{The role of the social worker}

A social worker plays an important role in the process of adoption in Dr. Kariadi Hospital, involving :

- a careful approach to the parents to appeal their understanding in the case of adoption;

- a sufficient preparation to involve foster parents in their responsibility to adopt a child. A thorough investigation should be conducted to ascertain their economic and educational background;

- a sufficient preparation in the child, e.g. the completion of the letter of transfer to the hospital. A special concern should be paid to the role of nurses who would act as mother sub stitutes for the child during his stay in the hospital. The role of a socia worker should not be kept in the process of adoption from its early stage to follow-up stage.

The role to the psychologist

The team is equipped with a psychologist. He is needed to help the team to investigate the child's mental behavior before any adoption takes place, to obtain enough background information about the parents' desire to adopt a child, and to observe the child's mental development before and after adoption.

\section{Discussion}

Due to unsatisfactory facilities and unskilled personnel, the process of adoption lacks sound preparation. Of 41 children being adopted, 18 have been visited; five have been officially approved by the Court, and the others are considered to be in the full care of the patents. The rights of the latter children are limited to receiving proper education and keeping the housework of their foster parents only (Dept. Social RI, 1972).

In a country with adoption law (Fischer, 1960), official approval by the local District Head only may be considered unlawful. In Indonesia this case has been accepted by traditional law (Dept. Social RI, 1972; Dept. Social FI, 1974; Ter Haar, 1960). The report above points out that the children were between 3-7 months old (30 children) when they were adopted. According to Backwin-Backwin (1960), the suggested age for adoption is the first six months of a child's early life. In his early life, the child is not aware yet of the environmental changes, so it should be well expected that no problems will arise in later development.

Spock (1965) suggested that adoption should take place when the child is between 8-10 years old. These ages are considered best for adoption since the the child may be asked to make a decision concerning his later life. This was suggested to stepfathers who would consider adopting a child. Whatever happens to a child it is wise to let the child know in advance about adoption problems. The 
best age is actually debatable. It is also considered that the earlier the age of the child the better; the age between 3-10 years is suggested since the child has already perceived some truth about adoption. This last case was found in a 4-year-old infant girl whose adoption had been officially approved. She told her mother the truth of what other people said about her that she was an adopted child. This problem invited a thoughtful follow-up. Report concerning health condition of those 18 children is sufficient. Psychological evaluation using Denver Development Screening Test indicated that no mental retardation among the children was observed; their IQ level was difficult to determine.

\section{REFERENCES}

1. BACKWIN, and BACKWIN, : Clinical management of behaviour disorders in children. 2nd ed. (Saunders, Philadelphia 1960).

2. DEPT. SOSIAL R.I.: Bimbingan kerja kesejahteraan masyarakat, keluarga dan anak (1972).

3. DEPT. SOSIAL R.I. : Laporan bagian K.K.A. perwakilan Departemen Sosial Jawa Tengah, $1973-1974$.

4. DEPT. SOSIAL R.I.: Panorama pekerjaan sosial di bidang kesejahteraan anak, keluarga dan masyarakat (Rapat Dinas Dept. Sosial, 6-10 Maret 1972, Djakarta).
5. FISCHER, C.C.: The role of the physician in environmental pediatrics. (Lansberger Med. Books, New York 1960).

6. ILG, F.L. and AMES, L.B. : Child behaviour. (Harper \& Brothers, New York 1963).

7. LEWIS, M. : Clinical aspects of child development. (Lea \& Febiger, Philadelphia 1973).

8. SPOCK, B.: Problem of parents. (Fawcett World Libr., New York 1965).

9. TER HAAR, B.: Asas-asas dan susunan hukum adat. (Pradnja Paramita, Djakarta 1960). 